\title{
EFFECT OF BIRTH WEIGHT, WEANING WEIGHT AND PREWEANING WEIGHT GAIN ON FERTILITY OF HOLSTEIN HEIFERS UNDER HOT MEXICAN CONDITIONS
}

\author{
Erika López¹, Francisco G. Véliz², Evaristo Carrillo³, Ángeles De Santiago¹, José E. García', Miguel Mellado* \\ ${ }^{1}$ Department of Animal Nutrition, Autonomous Agrarian University Antonio Narro, Saltillo, ${ }^{2}$ Department of Veterinary Science, Autonomous \\ Agrarian University Antonio Narro, Torreon, ${ }^{3}$ Techological Institute of Torreon, Torreon, Mexico \\ ${ }^{*}$ Corresponding author, E-mail: mmellbosq@yahoo.com
}

\begin{abstract}
Holstein calves ( $n=767$ ) froma commercial herd were used to determine the effect of birth weight(BW), weaning weight (WW) and preweaning average daily gain (ADG) on subsequent reproductive performance of heifers inseminated with sex-sorted semen in a hot environment $\left(25^{\circ} \mathrm{N}\right.$; mean annual temperature $\left.23.7^{\circ} \mathrm{C}\right)$. BW were divided into three groups: $<36,36-39 \mathrm{and}>39 \mathrm{~kg}$. WW were classified as $<66,66-74$ and $>74 \mathrm{~kg}$. ADG was categorized as $<450,450-520$ and $>520 \mathrm{~g}$. Of the heifers initially bred, $7.8 \%$ failed to conceive with $\geq 5$ services. Services/pregnancy were higher $(\mathrm{p}<0.01)$ in heifers with low BW $(2.42 \pm 1.39)$ than heifers with medium (2.13 \pm 1.38$)$ and high BW $(2.05 \pm 1.34)$. The proportion of heifers conceiving to the first service was lowest $(27.9 \% ; p<0.01)$ in heifers with the lowest BW compared to heifers weighing $36-39 \mathrm{~kg}$ (36.3\%) and $>39 \mathrm{~kg}$ at birth (40.3\%). However, neither BW, WW, nor ADG significantly affected ( $p>0.10$ ) all-service conception rate. Categories for $B W, W W$ and ADG did not influence abortion rate (3.5\% for all pregnant heifers). It was concluded that the heavier the Holstein calves are at birth and weaning, the shorter the age at calving under the present conditions, but low birth and weaning weight did not hamper all-service conception rate.
\end{abstract}

Key words: heifers; fertility; growth rate; abortion rate; conception rate

\section{Introduction}

The ability of dairy heifers to present an adequate growth rate for an earlier attainment of puberty, present normal estrous cycles, conceive at about $360 \mathrm{~kg}$, sustain gestation to term, calve without assistance close to two years, and start their first lactation without puerperal disorders are critical component for dairy operations $(1,2,3)$. Age at first calving is a vital factor affecting subsequent fertility and productivity of heifers $(4,5,6)$ because an earlier age at first calving reduces rearing

Received: 13 September 2017

Accepted for publication: 26 September 2017 costs due to decreased labor, feed and building costs. Also, body weight at birth and growth rate before puberty can affect the subsequent milk produced during the first lactation $(7,8,9)$ and survival rate to second lactation (10). Variability in preweaning and postweaning growth rates can lead to a large spread in the age at which heifers conceive for the first time (1). Optimum growth rates in replacement dairy heifers are necessary to breed their replacement heifers by about 15 months of age so that they calve for the first time at 24 months. This is broadly considered as the minimum age at which heifers are sufficiently grown to give birth without difficulty and to present a good milk yield during their first lactation. 
In zones of high ambient temperatures, heat stress may lead to reduced growth rates because neonatal calves have not developed adequate thermoregulation, which may be major contributors to the reduced weight gain during the first two weeks of life (11). Additionally, calves born to cows exposed to heat stress during late gestation (dry period) not only have compromised passive immune transfer but this heat stress has carryover effects beyond weaning, affecting negatively survival and milk production during the first lactation (12). Other authors have observed that Holstein calf performance in summer months either in extreme (13) or moderate climate conditions (14) showed a marked decline in growth rate as compared with winter conditions, which indicates that calves do not seem to be able to dissipate accumulated heat when daily high temperatures exceed their thermoneutral zone for healthy dairy calves.

Few studies have investigated the effect of preweaning growth variables in Holstein calves on their subsequent fertility in commercial dairy herds in hot environments. Furthermore, in many dairy record-keeping systems, calve and heifer growth rates are not recorded, thus maiden heifer growth performance is often unknown. The dairy industry would benefit significantly from being able to identify young age animals with altered birth weight and preweaning growth rate which would increase the risk of failing to conceive. The objective of this study was to determine the effect of birth weight (BW), weaning weight (WW) and preweaning average daily gain (ADG) on the reproductive performance of Holstein-Friesian heifers in a hot environment.

\section{Material and methods}

\section{Animals and management}

The study began in January, 2015 and ended in December of the same year, with the enrollment of 767 newborn calves (born as singletons) on one large commercial dairy farms located in northeastern Mexico $\left(26^{\circ} \mathrm{N} ; 23.7^{\circ} \mathrm{C}\right.$ mean annual temperature). Calves were sired by seven different bulls (artificial insemination, both sex-sorted and conventional semen) and these were equally distributed across this contemporary group. Calves were removed from the dam within $30 \mathrm{~min}$ of birth and before suckling could occur. Calves eligible for enrollment had to be singletons, weight $\geq 29$ $\mathrm{kg}$, and born unassisted or with minimal difficulty (easy pull). Calves were fed $3.8 \mathrm{~L}$ of colostrum using an esophageal tube feeder by about $2 \mathrm{~h}$ of age. The average calf in the study weighed 38.4 $\mathrm{kg}$, so $3.8 \mathrm{~L}$ of colostrum was approximately $10 \%$ of BW. Immediately after the colostrum feeding, calves were moved into individual $3.8-\mathrm{m}^{2}(2.5 \times 1.5$ $\mathrm{m})$ open roofed pen, without bedding and provided twice-daily feedings (at 0700 and $1700 \mathrm{~h}$ ) of $2 \mathrm{~L}$ of a commercial milk replacer containing $20 \%$ crude fat and $22 \% \mathrm{CP}$, diluted to achieve $11 \% \mathrm{DM}$. Calves remained in these pens until weaning ( 7 to $8 \mathrm{wk}$ of age). Calves were open bucket fed and had access to free-choice water and pelleted calf starter. Body weight was measured with a mechanic scale at birth (before colostrum ingestion) and at weaning. Average daily gain was determined by subtracting weight at weaning from birth weight and then dividing by age (d) of calves.

After weaning the heifers were housed in groups of 30 animals per pen. The open-lot dirtfloor pens were located in a naturally ventilated area with plenty of shed structures. Feed bunks were located along the front of each pen allowing for $0.50 \mathrm{~m}$ of open bunk space per animal. Heifers were fed a TMR twice daily formulated to meet or exceed the nutritional requirements of Holstein heifers weighing $250 \mathrm{~kg}$ and gaining $0.8 \mathrm{~kg} / \mathrm{d}$ (15). Diets contained soybean meal and ground shelled corn as the base ingredients of concentrate mix; the forage portion of the diet was oat hay. Heifers were fed ad libitum with an approximate refusal of $10 \%$ of that offered. Orts were cleaned out of the feed bunks each day, with new feed delivered twice daily. Water was available ad libitum through a water bowl in each pen. Heifers were also given ad libitum access to a trace mineral supplement.

\section{Reproductive management}

All heifers were vaccinated against diseases that impair reproduction functions, such as brucellosis (Brucella abortus RB51 ${ }^{\circledR}$, Intervet Mexico, Huixquilucan, Mexico), infectious bovine rhinotracheitis, bovine viral diarrhea, bovine respiratory syncytial virus, para-influenza and leptospirosis (5-varieties; Gold FP5 ${ }^{\circledR}$, Zoetis, Mexico D.F., Mexico).

Heifers were submitted for AI when detected in estrus after visual observation twice daily. Artificial 
insemination (AI) was conducted following the standard a.m./p.m. rule. Commercial sex-sorted frozen-thawed semen from 5 different bulls from the USA was used across all months of the year. The straws contained 2 million spermatozoa and the sperm cells were deposited in the uterine body. Bulls were almost used equally across heifers included in the study, therefore, bulls were fairly evenly distributed among the contemporary heifers.

Pregnancy was detected by rectal palpation of the uterus by the herd veterinarian (same veterinarian throughout the study period) about 45 days post-AI. First-service conception rate was defined as the percentage of heifers that conceived at the time of their first breeding. All-service conception rate was defined as the number of heifers that conceived out of the ones that were inseminated $\leq 5$ services. Days to first service was defined as the time (d) from when a heifer was born until the first time she was bred. Interval to pregnancy was the number of days from calving to AI resulting in pregnancy among the heifers inseminated. Heifers not pregnant with $\leq 5$ services days was calculated as the number of heifers which did not get pregnant with a maximum of 5 services, divided by the number of heifers to be bred (expressed as a percentage).

\section{Statistical analysis}

The GENMOD procedure of SAS (SAS Inst., Inc., Cary, NC) was implemented to assess the effect of BW categories, weaning weight classes and preweaning average daily gain on first-service conception rate, all-service conception rate, abortion rate and calving rate. The procedure used a generalized linear model based on the logit transformation and binominal distribution of data. For continuous variables (interval to first AI, birth to conception interval among pregnant heifers and age at first calving), general linear models (GLM of SAS) procedure was used. Month of birth was included in the model as a covariate. The differences between individual groups were compared by the PDIFF option after least square means (LS means). After limiting the number of services per conception to heifers with a confirmed pregnancy diagnosis, the effect of growth traits on the number of services per conception was evaluated by the bivariate Wilcoxon rank sum test (non-parametric; proc npar1way; SAS). This procedure was used because the UNIVARIATE option of SAS indicated that services per pregnancy did not follow a normal distribution. The CORR procedure of SAS was used to determine the correlation coefficients between the growth traits. Statistical significance was defined as $\mathrm{P}<0.05$.

\section{Results}

The reproductive performance of heifers according to their BW is presented in Table 1 . The time to the first insemination was ten days shorter $(p<0.01)$ for heifers with heavier BW than heifers with medium and low BW. No difference for this variable was observed between heifers whose BW was between 36 and $39 \mathrm{~kg}$ and those weighing $<36 \mathrm{~kg}$ at calving.

As expected, the age at conception was much shorter $(\mathrm{p}<0.01)$ in heifers with the heaviest BW than heifers that were lighter at calving. BW significantly affected first-service conception rate with the heaviest heifers at parturition having the highest first-service conception rates and the heifers with light birth weights presenting the lowest first-service conception rates (Table 1). However, all-service conception rate did not differ $(p>0.10)$ among groups regarding $\mathrm{BW}$. Abortion rate was higher $(p<0.01)$ for heifers with the medium BW, with no differences between the heaviest and lightest heifers at birth. BW had no significant effect on percentage of heifers failing to conceive with a maximum of five services.

Heifer fertility in relation to their WW is presented in Table 2. The average age to first breeding was shorter $(\mathrm{p}<0.01)$ in those heifers with the highest WW compared with heifers with low WW. Likewise, heifers with the heaviest WW presented shorter $(p<0.05)$ days to conception and at calving than heifers with lighter weight at weaning. Conception rate at first service of the heaviest heifers at weaning differed $(p<0.01)$ by as much as 13 percentage points compared with heifers with the lightest WW. Both all-service conception rate and calving rate did not differ among groups of heifers regarding WW.

The reproductive performance of heifers according to their preweaning ADG is presented in Table 3. Both groups of heifers with medium and high preweaning growth rate were younger $(\mathrm{p}<0.01)$ at first breeding than heifers with the 
Table 1: Nulliparous Holstein heifer fertility in relation to their birth weight

\begin{tabular}{lccc}
\hline Item & \multicolumn{3}{c}{ Birth weight $(\mathrm{kg})$} \\
\hline & $<36(\mathrm{n}=233)$ & $36-39(\mathrm{n}=197)$ & $>39(\mathrm{n}=337)$ \\
Age at first breeding (days) & $400 \pm 36^{\mathrm{a}}$ & $400 \pm 41^{\mathrm{a}}$ & $390 \pm 26^{\mathrm{b}}$ \\
Age at conception (days) & $434 \pm 46^{\mathrm{a}}$ & $424 \pm 42^{\mathrm{b}}$ & $419 \pm 36^{\mathrm{b}}$ \\
Age at calving (months) & $23.9 \pm 1.6^{\mathrm{a}}$ & $23.5 \pm 1.4^{\mathrm{b}}$ & $23.3 \pm 1.2^{\mathrm{b}}$ \\
Services / pregnancy (pregnant heifers) & $2.42 \pm 1.39^{\mathrm{a}}$ & $2.13 \pm 1.38^{\mathrm{b}}$ & $2.05 \pm 1.34^{\mathrm{b}}$ \\
First-service conception rate (\%) & $27.9(65 / 233)^{\mathrm{a}}$ & $36.3(57 / 157)^{\mathrm{b}}$ & $40.3(152 / 377)^{\mathrm{b}}$ \\
All-service conception rate (\%) & $90.1(210 / 233)$ & $94.9(149 / 157)$ & $92.6(349 / 377)$ \\
Abortion rate (\%) & $2.4(5 / 210)^{\mathrm{a}}$ & $6.7(10 / 149)^{\mathrm{b}}$ & $2.9(10 / 349)^{\mathrm{a}}$ \\
Failure to conceive with 5 services (\%) & $9.9(23 / 233)$ & $5.1(8 / 157)$ & $7.4(28 / 377)$ \\
Calving rate (\%) & $88.0(205 / 233)$ & $88.9(139 / 157)$ & $89.9(339 / 377)$ \\
\hline
\end{tabular}

a,bValues followed by the same superscript do not differ $(\mathrm{p}<0.01)$.

Table 2: Nulliparous Holstein heifer fertility in relation to their weaning weight

\begin{tabular}{lccc}
\hline Item & \multicolumn{3}{c}{ Weaning weight $(\mathrm{kg})$} \\
\hline & $<66(\mathrm{n}=282)$ & $65-74(\mathrm{n}=228)$ & $>74(\mathrm{n}=257)$ \\
Age at first breeding (days) & $399 \pm 34^{\mathrm{a}}$ & $395 \pm 33^{\mathrm{ab}}$ & $391 \pm 31^{\mathrm{b}}$ \\
Age at conception (days) & $428 \pm 37^{\mathrm{a}}$ & $428 \pm 46^{\mathrm{a}}$ & $418 \pm 39^{\mathrm{b}}$ \\
Age at calving (months) & $23.7 \pm 1.3^{\mathrm{a}}$ & $23.6 \pm 1.6^{\mathrm{a}}$ & $23.3 \pm 1.3^{\mathrm{b}}$ \\
Services / pregnancy (pregnant heifers) & $2.28 \pm 1.28$ & $2.18 \pm 1.37$ & $2.02 \pm 1.30$ \\
First-service conception rate (\%) & $29.1(82 / 282)^{\mathrm{a}}$ & $36.8(84 / 228)^{\mathrm{b}}$ & $42.0(108 / 257)^{\mathrm{b}}$ \\
All-service conception rate (\%) & $89.7(253 / 282)$ & $93.0(212 / 228)$ & $94.2(242 / 257)$ \\
Abortion rate (\%) & $2.8(7 / 253)$ & $4.7(10 / 212)$ & $3.3(8 / 242)$ \\
Failure to conceive with 5 services (\%) & $9.9(28 / 282)$ & $7.0(16 / 228)$ & $5.8(15 / 257)$ \\
Calving rate (\%) & $87.6(247 / 282)$ & $88.6(202 / 228)$ & $91.1(234 / 257)$ \\
\hline
\end{tabular}

a,bValues followed by the same superscript do not differ $(\mathrm{p}<0.01)$.

Table 3: Nulliparous Holstein heifer fertility in relation to their average preweaning daily weight gain

\begin{tabular}{lccc}
\hline Item & \multicolumn{3}{c}{ Average daily gain $(\mathrm{g})$} \\
\hline & $<430(\mathrm{n}=223)$ & $430-520(\mathrm{n}=222)$ & $>520(\mathrm{n}=322)$ \\
Age at first breeding (days) & $401 \pm 33^{\mathrm{a}}$ & $393 \pm 30^{\mathrm{b}}$ & $393 \pm 35^{\mathrm{b}}$ \\
Age at conception (days) & $427 \pm 37$ & $424 \pm 38$ & $423 \pm 45$ \\
Age at calving (months) & $23.6 \pm 1.3$ & $23.5 \pm 1.3$ & $23.5 \pm 1.5$ \\
Services / pregnancy (pregnant heifers) & $2.19 \pm 1.22$ & $2.27 \pm 1.44$ & $2.10 \pm 1.30$ \\
First-service conception rate (\%) & $31.8(71 / 223)$ & $37.8(84 / 222)$ & $37.0(119 / 322)$ \\
All-service conception rate (\%) & $89.7(200 / 223)$ & $92.8(206 / 222)$ & $93.5(301 / 322)$ \\
Abortion rate (\%) & $3.5(7 / 200)$ & $3.4(7 / 206)$ & $3.7(11 / 301)$ \\
Failure to conceive with 5 services (\%) & $10.3(23 / 223)$ & $7.2(16 / 222)$ & $6.5(21 / 322)$ \\
Calving rate (\%) & $86.6(193 / 223)$ & $89.6(199 / 222)$ & $90.1(290 / 322)$ \\
\hline
\end{tabular}

a,bValues followed by the same superscript do not differ $(\mathrm{p}<0.01)$. 
lowest growth rate before weaning. Preweaning ADG did not affect all other reproductive variables.

\section{Discussion}

The calf population exhibited a 1.8 -fold natural variation in birth weight $(29-51 \mathrm{~kg})$. This large variability in birth weight reflects ample growth rates during prenatal development. In the present study, it is believed that environmental factors were more important in influencing low BW than genetic factors. Chronic exposure in utero to elevated environmental temperatures, as the ones experienced by pregnant cows in the present study, greatly reduce birth weight of calves $(11,12)$ and low BW calves fail to attain the same weight at 12 mo of age achieved in calves from dams not experience heat stress when dry (16).

Surviving calves with birth weight $<36 \mathrm{~kg}$ showed suboptimal values for most reproductive variables compared with heavier calves at birth. For instance, lighter calves at birth required more days to first breeding and conception, which led to a greater age to first calving. For this last trait, it has been also reported that heifers with high birth weight were younger at first calving (17). Calves that were born small did not exhibit early catch-up growth to weaning at eight weeks of age $(r=0.16$ for $\mathrm{BW}$ and $\mathrm{ADG}$ ); therefore, it seems that lighter calves at birth resulted in delayed puberty in these animals. An association between body weight gain and timing of puberty has been reported in heifers $(18,19)$. Also, low BW calves presented lower firstservice conception rate and greater services per conception than heavier calves at birth.

Overall first-service conception rate was 36\%, which is close to the $39 \%$ achieved in heifers bred with sexed semen in intensive systems in the United States (20). All-services conception rate in heifers with low BW was similar than that observed in medium and high BW heifers. This result is in line with observations of other researchers $(21,22)$ who reported that lighter heifer calves at birth continued to have lesser BW during their first lactation, but this did not affect subsequent fertility. Thus, lower calf BW in this study was significantly associated with future all-services pregnancy rate but was negatively associated with other important reproductive variables such as the interval from birth to first calving. Age at first calving is an important factor in determining the length of the nonproductive period as well as affecting subsequent fertility $(1,5)$. The decision on when to breed heifers is a management one, but it is influenced by pre-and post-weaning growth rate of heifers (23). The fertility of the heifers at this point will then affect age at first calving on any particular dairy farm.

Heifers whose birth weight was very low $1<36$ $\mathrm{kg}$ ) calved at 23.8 months which is within the range of 23 to 24.5 mo considered to maximize dairy farm profitability $(1,24)$. These data do not confirm previous reports of delays in age to first calving in dairy cattle in other temperate countries $(5,6,25)$. These data suggest that even with very low BW heifers in the present study achieved the first calving at about 24 mo, which suggests that calves with low birth weight can subsequently show accelerated growth when feeding conditions improve, apparently compensating for the initial setback. Research suggests that, although compensatory growth can bring rapid benefits, it is also associated with a variety of costs that are not evident until later in adult life. These data also show that heifers with poor initial conception rates or with higher services per conception clearly calved later than those which conceive earlier in life, but, at the end, these heifers attained adequate pregnancy rates and did not present a calving delay for maiden dairy heifers.

The intervals from birth to first breeding and birth to conception was longer in heifers with low WW compared with heavier heifers at weaning. It is possible that lighter heifers at weaning reached puberty later than animals with higher WW. It has been observed that prepubertal growth rate is positively associated with the proportion of heifers cycling at the breeding age (26). This situation would increase cases of first ovulations not accompanied by overt estrus signs and the occurrence of a short luteal phase, with the subsequent fall in progesterone helping to promote the first behavioral changes (27). On the other hand, probably puberty was reached earlier in the heaviest heifers at weaning as a result of the inverse relationship between growth rate and age at puberty $(28,29)$.

First-service conception rate was higher in heifers with high WW compared with light heifers at weaning. Probably the heaviest heifers at weaning presented more mature reproductive tracts as a result of alternating peaks of oestradiol and progesterone post-pubertally. This possibly 
improved fertility as evidence shows pregnancy rates of $57 \%$ and $78 \%$ when beef heifers were served at the first compared with the third observed oestrus (30). On the other hand, heifers with lighter WW probably were served with fewer estrous cycles previous to their first insemination which resulted in lower conception rate at first service and greater services per conception. Similar to other studies where increased WW has been associated with lower age at calving (31), in the present study heavier heifers at weaning had a shorter birth to calving interval.

Preweaning ADG ranged from 175 to $912 \mathrm{~g}$. All heifers were managed in the same way, so growth rate did not relate to plane of nutrition provided. This excessive variation was probably linked with heat stress or disease $(32,33)$. The only reproductive variable affected by preweaning ADG was age at first service with a longer interval from birth to first insemination in heifers with the lowest preweaning ADG. Possibly the low growth rate of calves in this study prevailed during the prepubertal period, which could have delayed the occurrence of estrus. Heavier heifers, on the other hand, probably attained puberty earlier as time to puberty is negatively associated with prepubertal level of feeding (26). Additionally, heifers with greater prepubertal ADG present high amplitude LH pulses and high-frequency low amplitude LH pulses at a younger age (34). Other authors have observed that heifers with faster growth rates and higher concentrations of insulin-like growth factor-I (IGF-I) and glucose, breed earlier (2).

Preweaning ADG did not affect all-services pregnancy rate, which is in line with findings of other researchers who have found that post-natal growth rate does not influence future reproductive success in sheep (35) and dairy cattle (6).

Under the conditions prevailing in this experiment, which ensured maximum nutrient intake from birth to gestation, preweaning daily weight gain did not impair most of the measured reproductive functions. Thus, our results suggest that the type of preweaning growth in well-fed calves is not an important consideration for future reproductive performance of Holstein heifers.

In conclusion, a significant finding of the current study was that light birth and weaning weights had an impact on some subsequent fertility traits in maiden heifers. However, low birth weights did not hamper important reproductive traits such as all-service conception rate. Additionally, low birth and weaning weight were not an obstacle to begging artificial insemination breeding by $<13.5$ months, which resulted in calvings close to the recommended 24 months of age. Thus, despite the fact that birth and weaning weights alters some reproductive performance of Holstein heifers in a hot environment, this should not be considered when selecting replacement animals as catch up' feeding before puberty allow these heifers to achieve target live weight to calve close to 24 months.

\section{Acknowledgement}

The authors declare that there is no conflict of interest that could be perceived as prejudicing the impartiality of the research reported.

\section{References}

1. Ettema JF, Santos JE. Impact of age at calving on lactation, reproduction, health, and income in first-parity Holsteins on commercial farms. J Dairy Sci 2004; 87: 2730-42.

2. Brickell JS, Bourne N, McGowan MM, Wathes DC. Effect of growth and development during the rearing period on the subsequent fertility of nulliparous Holstein-Friesian heifers. Theriogenology 2009; 72: 408-16.

3. Wathes DC, Pollott GE, Johnson KF, Richardson $\mathrm{H}$, Cooke JS. Heifer fertility and carry over consequences for life time production in dairy and beef cattle. Animal 2014; 8(Suppl 1): 91-104.

4. Nilforooshan M, Edriss M. Effect of age at first calving on some productive and longevity traits in Iranian Holsteins of the Isfahan province. J Dairy Sci 2004; 87: 2130-5.

5. Evans RD, Wallace M, Garrick DJ, Dillon P, Berry DP Olori V. Effects of calving age, breed fraction and month of calving on calving interval and survival across parities in Irish spring-calving dairy cows. Livest Sci 2006; 100: 216-30.

6. Cooke JS, Cheng Z, Bourne NE, Wathes DC. Association between growth rates, age at first calving and subsequent fertility, milk production and survival in Holstein-Friesian heifers. Open $\mathrm{J}$ Anim Sci 2013; 3(1): e1-12. http://file.scirp.org/ Html/1-1400108_27069.htm

7. Zanton GI, Heinrichs AJ. Meta-analysis to assess effect of prepubertal average daily gain of Holstein heifers on firstlactation production. J 
Dairy Sci 2005; 88: 3860-7.

8. Bach A, Ahedo J. Record keeping and economics of dairy heifers. Vet Clin North Am Food Anim Pract 2008; 24: 117-38.

9. Van De Stroet D, Calderón Díaz J, Stalder K, Heinrichs A, Dechow C. Association of calf growth traits with production characteristics in dairy cattle. J Dairy Sci 2016; 99: 8347-55.

10. Bach A. Associations between several aspects of heifer development and dairy cow survivability to second lactation. J Dairy Sci 2011; 94: 1052-7.

11. Tao S, Dahl GE. Invited review: heat stress effects during late gestation on dry cows and their calves. J Dairy Sci 2013; 96: 4079-93.

12. Monteiro APA, Tao S, Thompson IMT, Dahl GE. In utero heat stress decreases calf survival and performance through the first lactation. J Dairy Sci 2016; 99: 8443-50.

13. Marai IFM, Habeeb AA, Daader AH, Yousef, HM. Effects of Egyptian subtropical summer conditions and the heat-stress alleviation technique of water spray and a diaphoretic on the growth and physiological functions of Friesian calves. J Arid Environ 1995; 30: 219-25.

14. Wiedmeier, RD, Young AJ, Hammon DS. Frequent changing and rinsing of drinking water buckets improved performance of hutch-reared Holstein calves. Bovine Pract 2005; 40: 1-8.

15. National Research Council. Nutrient requirements of dairy cattle. 7 th rev. ed. Washington : National Academy Press, 2001.

16. Dahl GE, Tao S, Monteiro APA. Effects of late-gestation heat stress on immunity and performance of calves. J Dairy Sci 2016; 99: 3193-8.

17. Ghoraishy SH, Rokouei M. Impact of birth weight of Iranian Holstein calves on their future milk production and reproductive traits. J Livest Sci Technol 2013; 1: 41-6.

18. Lammers BP, Heinrichs AJ Kensinger RS. The effects of accelerated growth rates and estrogen implants in prepubertal Holstein heifers on estimates of mammary development and subsequent reproduction and milk production. J Dairy Sci 1999; 82: 1753-64.

19. Brito LF, Barth AD, Rawlings NC, et al. Effect of nutrition during calfhood and peripubertal period on serum metabolic hormones, gonadotropins and testosterone concentrations, and on sexual development in bulls. Domest Anim Endorinol 2007; 33: 1-18.

20. Norman HD, Hutchison JL, Miller RH. Use of sexed semen and its effect on conception rate, calf sex, dystocia, and stillbirth of Holsteins in the United States. J Dairy Sci 2010; 93: 3880-90.

21. Hyun-Joo L, Jun-Kyu S, Ho-Beak Y, KwangSoo B, Eung-Gi K. Effect of calf birth weight on the subsequent fertility of Holstein heifers. J Embryo Transf 2012; 27: 81-5.

22. Swali A, Wathes DC. Influence of the dam and sire on size at birth and subsequent growth, milk production and fertility in dairy heifers. Theriogenology 2006; 66: 1173-84.

23. Carson AF, Dawson LER, McCoy MA, Kilpatrick DJ Gordon FJ. Effects of rearing regime on body size, reproductive performance and milk production during the first lactation in high genetic merit dairy herd replacements. Anim Sci 2002; 74: 553-65.

24. Tozer PR Heinrichs AJ. What affects the costs of raising replacement dairy heifers: a multiplecomponent analysis. J Dairy Sci 2001; 84: 1836-44.

25. Pirlo, G, Miglior, F and Speroni, M. Effect of age at first calving on production traits and on difference between milk returns and rearing costs in Italian Holsteins. J Dairy Sci 2000; 83: 606-8.

26. Macdonald KA, Penno JW, Bryant AM, Roche JR. Effect of feeding level pre- and post-puberty and body weight at first calving on growth, milk production, and fertility in grazing dairy cows. J Dairy Sci 2005; 88: 3363-75.

27. Gasser CL. Joint Alpharma-Bef Species Symposium: considerations on puberty in replacement beef heifers. J Anim Sci 2013; 91: 1336-40.

28. Funston RN, Martin JL, Larson DM, Roberts AJ. Physiology and Endocrinology Symposium: nutritional aspects of developing replacement heifers. J Anim Sci 2012; 90: 1166-71.

29. Perry GA. Physiology and Endocrinology symposium: harnessing basic knowledge of factors controlling puberty to improve synchronization of estrus and fertility in heifers. J Anim Sci 2012; 90: 1172-82.

30. Byerley DJ, Staigmiller RB, Berardinelli JG, Short RE. Pregnancy rates of beef heifers bred either on pubertal or third estrus. J Anim Sci 1987; 65: 645-50.

31. Raeth-Knight M, Chester-Jones H, Hayes $\mathrm{S}$, et al. Impact of conventional or intensive milk replacer programs on Holstein heifer performance through six months of age and during first lactation. J Dairy Sci 2009; 92: 799-809.

32. Tao S, Monteiro AP, Thompson IM, Hay- 
en MJ, Dahl GE. Effect of late gestation maternal heat stress on growth and immune function of dairy calves. J Dairy Sci 2012; 95: 7128-36.

33. Bazeley KJ, Barrett DC, Williams PD, Reyher KK. Measuring the growth rate of UK dairy heifers to improve future productivity. Vet J 2016; 212: 9-14.

34. Chelikani PK, Ambrose JD, Kennelly JJ. Ef- fect of dietary energy and protein density on body composition, attainment of puberty, and ovarian follicular dynamics in dairy heifers. Theriogenology 2003; 60: 707-25.

35. Gardner DS, Ozanne SE, Sinclair KD. Effect of the early-life nutritional environment on fecundity and fertility of mammals. Phil Trans R Soc B 2009; 364: 3419-27.

\title{
POVEZAVA MED TELESNO MASO, MASO OB ODSTAVITVI IN PRIRASTOM V ČASU PRED ODSTAVITVIJO NA PLODNOST TELIC HOLŠTAJN-FRIZIJSKE PASME V VROČIH KLIMATSKIH RAZMERAH MEHIKE
}

\author{
E. López, F. G. Véliz, E. Carrillo, Á. De Santiago, J. E. García, M. Mellado
}

Povzetek: Pri telicah holštajnske pasme $(n=767)$ iz komercialne črede smo ugotavljali vpliv telesne mase ob rojstvu, telesne mase ob odstavitviterdnevnega prirasta od rojstva do odstavitvenakasnejše reproduktivne sposobnostitelic, kismojih osemenili s semenom, ločenim glede na spol. Raziskava je potekala v vročih klimatskih razmerah $\left(25^{\circ} \mathrm{C}\right.$; povprečna letna temperatura $23.7^{\circ} \mathrm{C}$ ). Glede na telesno maso ob rojstvu smo telice razdelili v tri skupine: telice z maso, nižjo od $36 \mathrm{~kg}$, telice z maso med 36 in 39 kg ter telice z maso več kot $39 \mathrm{~kg}$. Glede na telesno maso ob odstavitvi pa smo razdelili telice v skupine z maso nižjo od 66 kg, maso od 66 do 74 kg ter maso, višjo od 74 kg. Enako smo živali razdelili v tri skupine glede na povprečni dnevni prirast in sicer na tiste, ki so v povprečju priraščale manj kot $450 \mathrm{~g}$ na dan, na tiste, ki so pridobivale od 450 do $520 \mathrm{~g}$ na dan, in na tiste, ki so imele povprečni prirast višji od $520 \mathrm{~g}$ na dan. Med vsemi telicami se jih 7,8 \% ni zabrejilo tudi po peti osemenitvi. Razmerje med osemenitvami in zabrejitvijo je bilo višje pri telicah z nizko porodno težo kot pri drugih dveh skupinah $(p<0,01)$, in sicer je bilo pri telicah z nizko porodno težo potrebno povprečno $2,42+1,39$ osemenitev do zabrejitve, pri skupinah s srednjo porodno težo je bilo potrebno $2,13+1,38$ osemenitev, pri telicah z višjo porodno težo pa le 2,05 + 1,34 osemenitev do zabrejitve. Delež telic, ki so se zabrejile ob prviosemenitvi, je bil prav tako najnižjiv skupiniz nizko porodno maso, le 27,9\%, medtemko je bilv skupinis srednjo porodno maso 36,3 , pri telicah z visoko porodno maso pa 40,35 (p<0,01). Končno število brejih telic se glede na število osemenitev ni razlikovalo med skupinami ne glede na porodno maso, maso ob odstavitvi ali povprečni dnevni prirast. Prav tako telesna masa ni vplivala na pogostnost zvrgov, ki je bila 3,5 \% pri vseh skupinah. Iz raziskave lahko ugotovimo, da se telice, ki so ob rojstvu težje, hitreje zabrejijo v toplih klimatskih razmerah, vendar pa telesna masa ob rojstvu ali ob odstavitvi ni povezana s povečanim pojavljanjem neplodnosti.

Ključne besede: telice; plodnost; prirast; pojavnost zvrgov; stopnja zabrejitve 